\title{
Endodontic retreatment due to secondary periapical injury: case report
}

Retratamento endodôntico por lesão periapical secundária: relato de caso

Retratamiento endodóntico debido a lesión periapical secundaria: reporte de caso

\section{Monica Soares de ALBUQUERQUE \\ Armiliana Soares NASCIMENTO ${ }^{1}$ \\ Cácio Lopes MENDES ${ }^{1}$}

Leonardo José Rodrigues de OLIVEIRA ${ }^{1}$

Marília de Lima SOARES ${ }^{1}$

Maria Catarina LAGO $^{2}$

Angela do NASCIMENTO2

Douglas Felipe de Lima e SILVA ${ }^{3}$

Rodivan BRAZ ${ }^{4}$

${ }^{1}$ PhD Student, Department of Restorative Dentistry, University of Pernambuco, Camaragibe, PE, Brazil

${ }^{2}$ MSc Student, Department of Restorative Dentistry, University of Pernambuco, Camaragibe, PE, Brazil

${ }_{3}^{3}$ Student of Multiprofessional Residences, of IMIP Instituto de Medicina Integral Prof. Fernando Figueira. Boa Vista, PE, Brazil

${ }^{4}$ Adjunct Professor, Biomaterials Research Center, University of Pernambuco, Camaragibe, PE, Brazil

\begin{abstract}
Pulp diseases commonly happens because of the actions of bacteriological factors and show their characteristic signs and symptoms over the time. With pulp necrosis, a degenerative process starts and when there is no early treatment, it is possible to occur periapical lesions as a result of aggression to the pulp. In cases of periapical secondary lesions, clinical signs and symptoms persist and are related to secondary infection due to persistent bacterial contamination, also to operative factors, inadequate obturation or poor coronary restoration. This study aimed to report a case of endodontic retreatment and clinical and radiographic follow-up for 8 years, of chronic periapical abscess case, in which after retreatment, clinical signs and symptoms are no longer observed and bone neoformation is noticed.

Descriptors: Periapical Diseases; Endodontics; Periapical Abscess.

\section{Resumo}

As doenças pulpares geralmente ocorrem devido às ações de fatores bacteriológicos e mostram seus sinais e sintomas característicos ao longo do tempo. Com a necrose pulpar, inicia-se um processo degenerativo e, quando não há tratamento precoce, é possível ocorrer lesões periapicais como resultado de agressão à polpa. Nos casos de lesões secundárias periapicais, os sinais e sintomas clínicos persistem e estão relacionados à infecção secundária por contaminação bacteriana persistente, também por fatores operatórios, obturação inadequada ou má restauração coronariana. Este estudo teve como objetivo relatar um caso de retratamento endodôntico e acompanhamento clínico e radiográfico por 8 anos, de abscesso periapical crônico, no qual após o retratamento, os sinais e sintomas clínicos não são mais observados e a neoformação óssea é notada.
\end{abstract}

Descritores: Doenças Periapicais, Endodontia; Abscesso Periapical.

\section{Resumen}

Las enfermedades pulpares ocurren comúnmente debido a las acciones de factores bacteriológicos y muestran sus signos y síntomas característicos a lo largo del tiempo. Con la necrosis pulpar, empieza un proceso degenerativo y cuando no se hace un tratamiento temprano, es posible que ocurran lesiones periapicales como resultado de la agresión a la pulpa. En los casos de lesiones secundarias periapicales, los signos y síntomas clínicos persisten y están relacionados con la infección secundaria debido a la contaminación bacteriana persistente y también debido a factores operativos, obturación inadecuada o mala restauración coronaria. Este estudio tuvo por objetivo informar un caso de retratamiento endodóntico y seguimiento clínico y radiográfico a lo largo de 8 años, de un caso de absceso periapical crónico, en el que, después del retratamiento, no se observan signos y síntomas clínicos y se nota neoformación ósea.

Descriptores: Enfermedades Periapicales; Endodoncia; Absceso periapical.

\section{INTRODUCTION}

The healing of periapical tissues is one of the most important goal of endodontic treatment. It may be reached through the elimination of microorganisms present in the infected root canal system and prevention of reinfection ${ }^{1,2}$. Inadequate preparations lead to unsatisfactory fillings and endodontic failures. Radiographically demonstrated by post-treatment periapical radiolucencies ${ }^{3}$. Some cross-sectional studies performed worldwide ${ }^{4-7}$ corroborate to this relationship.

Radiolucencies usually suggests the presence of periapical lesions, which are infectious diseases caused by microorganisms present in the root canal system and cause changes in the periapical level. These include chronic periapical abscesses, classified as an inflammatory reaction to infection and pulp necrosis. It is characterized by gradual onset, little or no discomfort, and intermittent discharge of pus through an associated sinus tract ${ }^{8}$.

Endodontic treatment outcome is usually measured 1 year after the endodontic treatment and is categorized as follows: (a) 'success', which includes two subcategories: 'complete healing' and 'incomplete healing' (clinical normality combined with reduced radiolucency and healing); (b) 'uncertain healing' (persistence of radiolucency in the absence of signs and symptoms, or presence of clinical signs / symptoms associated with incomplete healing radiography); c) failure (presence of clinical signs and symptoms combined with reduced or persistent radiolucency) $)^{9,10}$.

The recommended therapy when primary therapy is unsuccessful is endodontic retreatment and its main purpose is to return the appropriate clinical and biological conditions for periapical tissue repair $^{11,12}$. The success of retreatment can be analyzed by histological, clinical or radiographic evaluation of healing or by a combination of these. After a given follow-up period, as reported in many clinical studies ${ }^{13}$.

This study describes a case of endodontic retreatment due to chronic apical abscess with 
furcation and sinus tratus involvement, followed clinically and radiographically for 2 , and 8 years.

\section{CLINICAL CASE}

An 18-year-old female patient attended a private clinic complaining of a "bubble" in the inserted gingival region associated with the right lower first molar. During the diagnosis, the patient reported that the tooth had been endodontically treated 1 year ago. The patient didn't present feverish and had blood pressure within the normal range. The patient exhibit a satisfactory hygiene conditions during the intraoral clinical examination. There was presence of sinus tratus. A periodontal probe was performed, with normal periodontal limits. The tooth was sensitive to vertical percussion. Periapical radiographic examination revealed extensive periapical lesion covering the furcation area.

Prior to initiating case resolution, treatment alternatives and prognostic uncertainties were discussed and an informed consent was signed by the patient. After anesthesia with 4\% articaine with epinephrine $1 / 100,000(\mathrm{xxx})$ by the technique of inferior alveolar nerve block and rubber dam isolation, access surgery with short-shaft diamond spherical drill was performed. The treatment failure may ocurred due to lack of mechanical chemical preparation. After initial irrigation with $2.5 \%$ sodium hypochlorite $(\mathrm{NaOCl})$ the gutta percha was removed from the mesial canals with cotton tweezers, as there was only one "loose" cone in each canal and in the distal canal Retreatment Protaper (Dentsply / Sirona) was used, consisting of 3 electric motor-driven nickel-titanium instruments (X-Smart, Dentsply / Sirona). After removal of the gutta percha, the actual working length was determined with the Apex Mini Apex Locator (SybroEndo) and the mesial canals were prepared by Crown Down Protaper Universal technique (Dentsply / Maillefer, Bellaigues, Switzerland)), and finished with F3 and canal. Distal after retreatment Protaper was finished with F5 followed by $\mathrm{K} \# 60$ file, aided by abundant $2.5 \%$ hypochlorite irrigation, and 17\% EDTA for smearlayer removal followed by final hypochlorite irrigation at $2.5 \%$. The canals were dried with sterile paper cones (Dentsply / Maillefer), filled with calcium hydroxide paste and the cavity was temporarily restored for 15 days. After this period the root canals were filled by the modified Tagger technique, using AH-Plus (Dentsply) as the obturator cement. The access cavity was restored with Glass Ionomer (Vitremer - 3M) and Z100 Composite Resin (3M ESPE) and then occlusal adjustment was performed. Clinical and radiographic proservation was performed at 2-year and 8-year periods, where apical bone repair (bone neoformation) was observed, in addition to the absence of clinical symptoms (Figures 1-4).

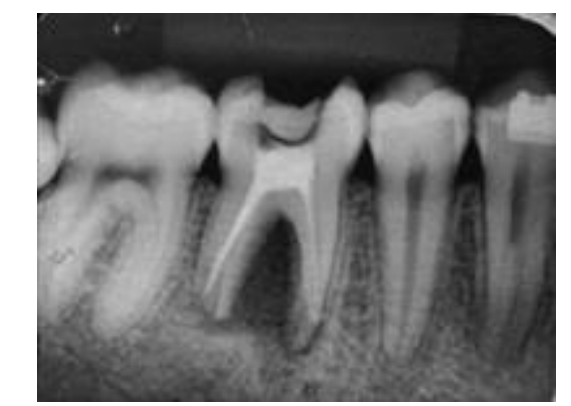

Figure 1: Sequence of treatment: initial radiography.

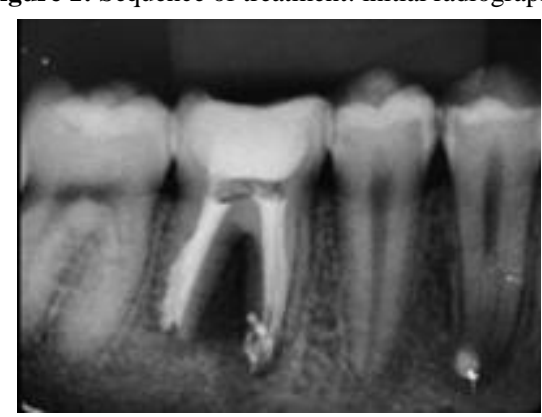

Figure 2: Sequence of treatment: immediate postoperative radiography.

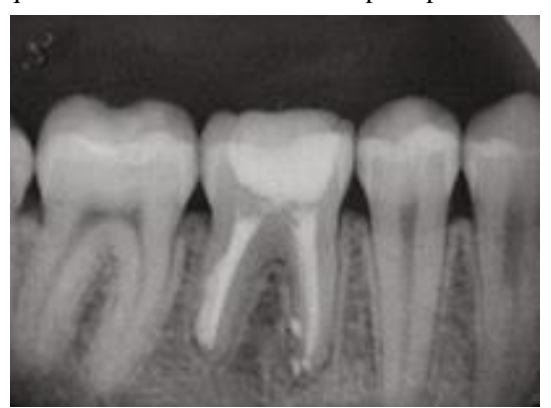

Figure 3: Sequence of treatment: two years after treatment.

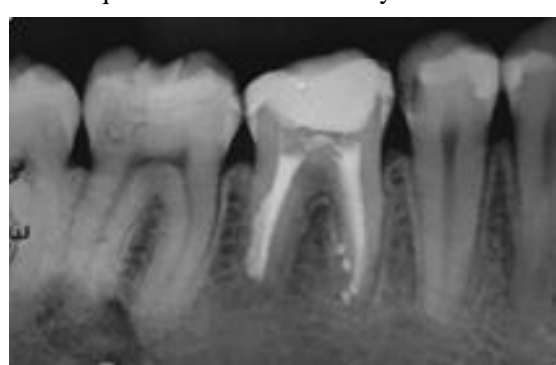

Figure 4: Sequence of treatment: eigth years after treatment.

DISCUSSION

According to Rubinstein and $\mathrm{Kim}^{14}$, teeth retreatment because of incorrect execution of endodontic treatment presents significantly better results than those whose treatment was well performed, thus corroborating to our study, whose chronic apical abscess was established or persisted due to poor execution. Thus, as a study by Estrela et al. ${ }^{15}$, in which stated that mistakes caused in primary therapy commonly occurs because of intraradicular infection, thus leading to endodontic failure.

This results in the need for endodontic retreatment in which consideration should be given to the importance of the complete removal of the obturator material and remains of pulp and smearlayer tissue, as the presence of remnant material within the root canal may serve as a shelter for the root canal microorganisms, hindering the complete sanitation of the root canal system ${ }^{16}$. 
According to Rossi-Fedele et al. ${ }^{17}$, retreatment techniques are not able to provide complete removal of root canal filler material. However, all are toxic and, according to Barbosa et al. ${ }^{18}$ and Zakariasen et al. ${ }^{19}$ whenever possible in retreatment, the use of these solvents should be avoided. Yet, Pecora et al. ${ }^{20}$ reported that orange oil was proposed as a biocompatible alternative to chloroform to remove gutta percha ${ }^{21}$ without any detrimental effect.

However, we chose to retreat the distal canal with a rotating technique without the use of solvents, a technique mechanized by its velocity. The choice for the Universal Retreatment Protaper (PTUR) was satisfactory, we were able to remove the gutter and access the apical third soon. Complementing the preparation with apical refinement using Protaper Universal F5 and hand file \# 60k. According to a study by Marques da Silva et al. ${ }^{22}$ in which the authors observed that rotational retreatment instruments need additional instrumentation.

Furthermore, the root canal system reinfection may occur when the coronary restoration is lost or infiltrated after the endodontic treatment has ended, leading to its failure, which calls attention to the use of restorative materials that diminish and / or prevent penetration of microorganisms in the root canal system ${ }^{23,24}$.

Root canal cleaning is performed through endodontic instruments and irrigating solution, and is subsequently effected by intracanal medication. Calcium hydroxide is the most commonly used medication in endodontics thanks to its ability to stimulate tissue repair and its antimicrobial potential $^{15,25}$. Choose this intracanal medication, lead to this study.

One of the most important step during the root preparation is the irrigation of the root canal system. Hypochlorite remains as a unique irrigant choice due to its properties as bactericidal action ${ }^{26}$; toxin neutralization ${ }^{27}$ and necrotic tissue dissolution $^{28}$. Due to these reasons we chose hypochlorite as irrigant in our study.

In order to assure an efficient root ducts sealing, it is important to choose a satisfactory obturation technique and obturator cement, as it will influence the repair of tissue lesions. The resin cement has good physical properties, such as dimensional stability, low solubility and higher bond strength to dentin when compared to other endodontic cements ${ }^{29}$, thanks to these characteristics was used AH Plus cement consisting of epoxy resin, associated to the lateral condensation technique in the distal canal and single cone in the mesial canals. These techniques promote adequate root canal filling, similar to thermal methods, where long-term success is similar ${ }^{30}$.
After finishing endodontic treatment, adhesive materials are the best choice to coronal seal. The rehabilitation technique used composite resin and Bulk fill flow resin as a base to maintain the dental structure, providing function and aesthetics, besides the protection of the obturator material ${ }^{31,24}$. Proservation through clinical and radiographic examination for eight years indicated successful endodontic retreatment, with lesion regression and bone neoformation ${ }^{11}$.

\section{CONCLUSION}

Endodontic retreatment remained a good choice to break off bacterial flow within the root canal system, allowing tissue repair of the periradicular region and absence of symptomatology. Besides that, reinstrumentation, intracanal calcium hydroxide medication enabled a conservative intervention capable of long-term treatment success.

\section{REFERENCES}

1. Alani AH. Endodontic treatment of bilaterally occurring four-rooted maxillary second molars: case report. J Can Dent Assoc. 2003;69(11):733-35.

2. Slowey RR. Radiographic aids in the detection of extra root canals. Oral Surg Oral Med Oral Pathol 1974;37(5):762-72

3. Bergenholtz G, Malmcrona E, Milthon R. Endodontic treatment and periapical status I. Radiographic evaluation of the frequency of endodontically treated teeth. Tandl€akartidningen. 1973; 65:64-73 (In Swedish, English summary).

4. Buckley M, Spangberg LS. The prevalence and technical quality of endodontic treatment in an American subpopulation. Oral Surg Oral Med Oral Pathol Oral Radiol Endod. 1995;79(1):92-100.

5. Saunders WP, Saunders EM, Sadiq J, Cruickshank E. Technical standard of root canal treatment in an adult Scottish sub-population. $\mathrm{Br}$ Dent J. 1997;182(10):382-86.

6. Segura-Egea JJ, Jimenez-Pinzon A, PoyatoFerrera M, Velasco-Ortega E, Rios-Santos JV. Periapical status and quality of root fillings and coronal restorations in an adult Spanish population. Int Endod J. 2004;37(8):525-30.

7. Kabak Y, Abbott PV. Prevalence of apical periodontitis and the quality of endodontic treatment in an adult Belarusian population. Int Endod J. 2005;38(4):238-45.

8. Glickman GN. AAE consensus conference on diagnostic terminology: background and perspectives. J Endod. 2009;35:1619.

9. Gutmann JL, Harrison JW. Surgical endodontics: an online study guide. Blackwell Scientific Publications; 1991.

10. Molven O, Halse A, Grung B. Incomplete healing (scar tissue) after periapical surgery - radiographic 
findings 8 to 12 years after treatment. J Endod. 1996;22(5):264-68.

11. Macedo, IL Retratamento endodôntico: opção terapêutica do insucesso endodôntico. BJHR. 2018;1(2):421-31.

12. Souza VC et al. Tratamento do insucesso endodôntico. Rev Odontol Bras Central. 2018; 27:44-48.

13. Bender IB, Seltzer S, Soltanoff W. Endodontic success - a reappraisal of criteria. Oral Surg Oral Med Oral Pathol. 1966; 22(6):790-802.

14. Rubinstein R A, Kim S. Long-term follow-up of cases considered healed one year after apical microsurgery. J Endod. 2002; 28(5):378-83.

15. Estrela $C$ et al. Characterization of successful root canal treatment. Braz Dent J. 2014; 25(1):3-11 http://dx.doi.org/10.1590/0103-6440201302356

16. Kaled GH et al. Retratamento endodôntico: análise comparativa da efetividade da remoção da obturação dos canais radiculares realizada por três métodos. RGO, Rev. gaúch. odontol. (Online). 2011;59(1):103-8.

17. Rossi-Fedele G, Ahmed HMA. Assessment of rootcanal filling removal effectiveness using micro-computedtomography: a systematic review. J Endod. 2017;43(4):520-26

18. Barbosa SV, Burkhard DH, Spanberg LSV. Cytotoxic effects of gutta-percha solvents. J Endod. 1994; 20(1):6-8.

19.Zakariasen KL, Brayton SM, Collinson DM. Efficient and effective root canal retreatment without chloroform. J Canad Dent Assoc. 1990; 56(6):509-12.

20. Pecora JD, Spano JC, Barbin EL. In vitro study on the softening of gutta-percha cones in endodontic retreatment. Brazilian. Braz Dent Journal. 1993; 4(1): 43-7.

21. Scelza MF et al. Comparative SEM evaluation of three solvents used in endodontic retreatment: an ex vivo study. Journal of Applied Oral Science. 2008; 16(1):24-9.

22. Marques da Silva B et al. Effectiveness of ProTaper, D-RaCe, and Mtwo retreatment files with and without supplementary instruments in the removal of root canal filling material. Int Endod J. 2012; 45(10):927-32

23. Song M1 et al. Analysis of the cause of failure in nonsurgical endodontic treatment by microscopic inspection during endodontic microsurgery. $\mathbf{J}$ Endod. 2011;37(11):1516-9.

24. Albuquerque MS et al. Sealing Capacity of Bulkfill Resin in Endodontically Treated Teeth. The Journal of Contemporary Dental Practice. 2019; 20(3): 311-17

25.Zancan RF, Vivan RR, Lopes MRM et al. Antimicrobial activity and physicochemical properties of calcium hydroxide pastes used as intracanal medication. J Endod. 2016. 42(12):1822-28.

26. Buttler TK, Crawford JJ. The detoxifying effect of varying concentrations of sodium hypochlorite on endotoxins. J Endod. 1982; 8(2):59-66.

27. Foley DB, Weine FS, Hagen JC, deObarrio JJ. Effectiveness of selected irrigants in the elimination of bacteroides meloninogenicus from the root canal system: an in vitro study. J Endod. 1983; 9(6):236-41.

28. Abou-Ran M, Oglesby SW. The effects of temperature, concentration and tissue type on the solvent ability of sodium hypochlorite. J Endod. 1981; 7(8):376-7.

29. Lee JK et al. Physicochemical Properties of Epoxy Resin-Based and Bioceramic-Based Root Canal Sealers. Bioinorg Chem Appl. 2017; 1-8.

30. Kandemir DG, Caliskan MK. A prospective Ramdomized Comparative Study of Cold Lateral Condensation Versus Core/Guta Percha in Teeth with Periapical Lesions. J Endod. 2016; 42(2):206-10

31. Karaman E, Keskin B, Inan U. Three-year clinical evaluation of class II posterior composite restorations placed with different techniques and flowable composite linings in endodontically treated teeth. Clin Oral Investig. 2017; 21(2):709-16

\section{CONFLICTS OF INTERESTS}

The authors declare no conflicts of interests.

\section{CORRESPONDING AUTHOR}

Monica Soares de Albuquerque

Faculdade de Odontologia de Pernambuco (FOP/UPE)

Av. Gal. Newton Cavalcanti, 1650, Tabatinga

54753-220 Camaragibe - PE, Brazil

+5581995432270.

e-mail address: santos.albuquerque@ hotmail.com

Received 31/03/2020

Accepted 08/06/2020 